\title{
Functional Interaction of Endothelin Receptors in Mediating Natriuresis Evoked by G Protein-Coupled Estrogen Receptor 1
}

\author{
(D) Eman Y. Gohar and (1DDavid M. Pollock \\ Cardio-Renal Physiology and Medicine, Division of Nephrology, Department of Medicine, University of Alabama at Birmingham, \\ Alabama (E.Y.G, D.M.P); and Department of Pharmacology and Toxicology, Faculty of Pharmacy, Alexandria University, \\ Alexandria, Egypt (E.Y.G)
}

Received September 4, 2020; accepted October 26, 2020

\begin{abstract}
The G protein-coupled estrogen receptor 1 (GPER1) mediates rapid estrogenic signaling. We recently reported that activation of GPER1 in the renal medulla evokes endothelin-1-dependent natriuresis in female, but not male, rats. However, the involvement of the $\mathrm{ET}$ receptors, $\mathrm{ET}_{\mathrm{A}}$ and $\mathrm{ET}_{\mathrm{B}}$, underlying GPER1 natriuretic action remain unclear. In this study, we used genetic and pharmacologic methods to identify the contributions of $\mathrm{ET}_{\mathrm{A}}$ and $E T_{B}$ in mediating this female-specific natriuretic effect of renal medullary GPER1. Infusion of the GPER1-selective agonist G1 (5 pmol $/ \mathrm{kg}$ per minute) into the renal medulla for 40 minutes increased $\mathrm{Na}^{+}$excretion and urine flow in anesthetized female $\mathrm{ET}_{\mathrm{B}}$-deficient $\left(\mathrm{ET}_{\mathrm{B}}\right.$ def) rats and littermate controls but did not affect blood pressure or urinary $\mathrm{K}^{+}$excretion in either group. Pretreatment with the selective $\mathrm{ET}_{\mathrm{A}}$ inhibitor ABT-627 $(5 \mathrm{mg} / \mathrm{kg}$, intravenous) abolished G1-induced natriuresis in $\mathrm{ET}_{\mathrm{B}}$ def rats. To further isolate the effects of inhibiting either receptor alone, we conducted the same experiments in anesthetized female
\end{abstract}

Sprague-Dawley (SD) rats pretreated or not with ABT-627 and/or the selective $\mathrm{ET}_{B}$ inhibitor $\mathrm{A}-192621$ (10 $\mathrm{mg} / \mathrm{kg}$, intravenous). Neither antagonism of $E T_{A}$ nor antagonism of $E T_{B}$ receptor alone affected the $\mathrm{G} 1$-induced increase in $\mathrm{Na}^{+}$excretion and urine flow in SD rats. However, simultaneous antagonism of both receptors completely abolished these effects. These data suggest that $\mathrm{ET}_{\mathrm{A}}$ and $\mathrm{ET}_{\mathrm{B}}$ receptors can mediate the natriuretic and diuretic response to renal medullary GPER1 activation in female rats.

\section{SIGNIFICANCE STATEMENT}

Activation of G protein-coupled estrogen receptor 1 (GPER1) in the renal medulla of female rats evokes natriuresis via endothelin receptors $A$ and/or $B$, suggesting that GPER1 and endothelin signaling pathways help efficient sodium excretion in females. Thus, GPER1 activation could be potentially useful to mitigate salt sensitivity in females.

\section{Introduction}

Hypertension is the leading cause of cardiovascular morbidity and mortality among women (Benjamin et al., 2018). In the United States, the prevalence of hypertension among adult women from 2017 to 2018 was $39.7 \%$ (Ostchega et al., 2020 ), and one in three deaths of women were attributed to cardiovascular disease (Benjamin et al., 2018). Hypertension control resulted in the largest reduction, 38\%, in cardiovascular mortality in women, according to NHANES (National Health and Nutrition Examination Survey) data modeling (Patel et al., 2015). Yet despite the availability of multiple antihypertensive regimens, almost half of hypertensive individuals in the United States do not have their blood pressure under control, highlighting the need for personalized therapeutic treatment options for the management of high blood pressure. Impaired natriuresis is a fundamental mechanism

This work was supported by the American Heart Association [Grant 18CDA34110010] (to E.Y.G.) and National Institutes of Health National Institute of Diabetes and Digestive and Kidney Diseases [Grant K99DK119413] (to E.Y.G.) and National Heart, Lung, and Blood Institute [Grant P01-HL136267] (to D.M.P.)

https://doi.org/10.1124/jpet.120.000322. in the initiation of hypertension (Hall et al., 2012; Elijovich et al., 2016). Therefore, it is vital that we expand our knowledge of the varied mechanisms of natriuresis. As studies indicate that women often receive suboptimal care for cardiovascular disease (Bairey Merz et al., 2015; Leifheit-Limson et al., 2015), improved understanding of the female-specific mechanisms underlying hypertension will help narrow the gender-related gap in health care.

We recently provided evidence for the G protein-coupled estrogen receptor 1 (GPER1) as a novel pronatriuretic factor in female rats but not male rats (Gohar et al., 2020). GPER1 is a nonclassic estrogen receptor that elicits rapid activation of signaling pathways (Revankar et al., 2005; Thomas et al., 2005). In particular, this heptahelical membrane-associated receptor has been shown to elicit protective actions in the cardiovascular and renal systems of several animal models (Lindsey et al., 2009, 2011; Jessup et al., 2010; Kurt et al., 2016; Liu et al., 2016; Qiao et al., 2018; Chang et al., 2019; Gohar et al., 2020). Indeed, many studies have shown that GPER1 activation mitigates salt-induced cardiovascular and kidney disease (Jessup et al., 2010; Lindsey et al., 2011; Liu et al., 2016), although the underlying mechanism has not been completely defined. Within the kidney, GPER1 expression has

ABBREVIATIONS: $E T-1$, endothelin-1; $\mathrm{ET}_{\mathrm{A}}$, endothelin receptor subtype $\mathrm{A} ; \mathrm{ET}_{\mathrm{B}}$, endothelin receptor subtype $\mathrm{B} ; \mathrm{ET}_{\mathrm{B}}$ def, $\mathrm{ET}_{\mathrm{B}}$-deficient; $\mathrm{GPER}$, $\mathrm{G}$ protein-coupled estrogen receptor 1; MAP, mean arterial pressure; SD, Sprague-Dawley; TG, transgenic. 
been detected in tubular and epithelial cells (Lindsey et al., 2011; Cheng et al., 2014). We found that activation of GPER1 within the renal medulla of female rats promotes an increase in urinary $\mathrm{Na}^{+}$excretion via an endothelin-1 (ET-1)-dependent pathway (Gohar et al., 2020), but the contribution of endothelin receptors $\mathrm{ET}_{\mathrm{A}}$ and/or $\mathrm{ET}_{\mathrm{B}}$, involved in GPER1-induced natriuretic effect, have not been identified.

ET-1 is a well established pronatriuretic peptide that inhibits the activity of epithelial $\mathrm{Na}^{+}$channels and $\mathrm{Na}^{+} / \mathrm{K}^{+}$ ATPase (Zeidel et al., 1989; Kohan, 2011; Speed et al., 2015). In fact, ET-1 has a fundamental role in the maintenance of blood pressure and $\mathrm{Na}^{+}$homeostasis (Kohan, 2011; Speed et al., 2015). ET-1 elicits downstream actions via activation of the $\mathrm{G}$ protein-coupled receptors $\mathrm{ET}_{\mathrm{A}}$ and $\mathrm{ET}_{\mathrm{B}}$, which are expressed at high levels within the medulla of the kidney (Kohan et al., 2011). In particular, established evidence indicates that the $\mathrm{ET}_{\mathrm{B}}$ receptor has a central role in mediating the excretory effects of ET-1 (Ge et al., 2006), and loss of $\mathrm{ET}_{\mathrm{B}}$ receptor function results in a salt-sensitive phenotype (Hocher and Ehrenreich, 2002). However, natriuretic actions have also been ascribed to $\mathrm{ET}_{\mathrm{A}}$ receptors specifically in female rats under conditions of $\mathrm{ET}_{\mathrm{B}}$ receptor dysfunction (Nakano and Pollock, 2009). Additional evidence indicates that $\mathrm{ET}_{\mathrm{A}}$ and $\mathrm{ET}_{\mathrm{B}}$ receptors may act synergistically to facilitate $\mathrm{Na}^{+}$and water excretion (Ge et al., 2008; Nakano and Pollock, 2009; Boesen and Pollock, 2010). Of note, ET receptor antagonists, combined $\mathrm{ET}_{\mathrm{A}}$ and $\mathrm{ET}_{\mathrm{B}}$ or selective $\mathrm{ET}_{\mathrm{A}}$ receptor-selective agents, are currently used in the treatment of pulmonary hypertension (Boesen, 2015). Despite limitations related to higher doses causing fluid retention, $\mathrm{ET}_{\mathrm{A}}$ receptor-selective agents hold promise in the management of hypertension and renal disease (Meyers and Sethna, 2013; Boesen, 2015; Pollock and Pollock, 2019), whereas concomitant $\mathrm{ET}_{\mathrm{B}}$ receptor antagonists are not beneficial clinically, as they induce vasoconstriction and salt and water retention (Dhaun and Webb, 2008; Meyers and Sethna, 2013; Moorhouse et al., 2013).

The current study was designed to use genetic and pharmacologic approaches to identify the relative contributions of $\mathrm{ET}_{\mathrm{A}}$ and $\mathrm{ET}_{\mathrm{B}}$ receptors to renal medullary GPER1-induced natriuresis. Considering that the pronatriuretic effects of GPER1 are evident in female rats but absent in males (Gohar et al., 2020), the experiments in this study were conducted solely in female animals.

\section{Materials and Methods}

Animals. All experiments were conducted in accordance with the Guide for the Care and Use of Laboratory Animals and the ARRIVE ((Animal Research: Reporting of In Vivo Experiments) guidelines (Kilkenny et al., 2010) and approved and monitored by the University of Alabama at Birmingham Institutional Animal Care and Use Committee. Female $\mathrm{ET}_{\mathrm{B}}$-deficient $\left(\mathrm{ET}_{\mathrm{B}}\right.$ def) rats and transgenic (TG) control littermates were obtained from our in-house colony. $\mathrm{ET}_{\mathrm{B}}$-deficient rats were originally produced from the spotting lethal rat, which has a naturally occurring 301-bp deletion in the gene encoding $\mathrm{ET}_{\mathrm{B}}$ that results in a lethal phenotype of congenital intestinal megacolon (Gariepy et al., 1998). This model was rescued by expressing a human $\mathrm{ET}_{\mathrm{B}}$ transgene only in sympathetic tissue using the human dopamine- $\beta$-hydroxylase promoter (Gariepy et al., 1998). Thus, the $\mathrm{ET}_{\mathrm{B}}$ def rats express $\mathrm{ET}_{\mathrm{B}}$ receptors only in nervous tissue because of the transgene, whereas TG controls express the transgene and the normal $\mathrm{ET}_{\mathrm{B}}$ receptor. In total, $20 \mathrm{ET}_{\mathrm{B}}$ def and $\mathrm{TG}$ rats were used. Separate experiments used an additional 38 Sprague-Dawley
(SD) rats purchased from Envigo (Indianapolis, IN). All rats were aged 18-22 weeks and weighed $200-300 \mathrm{~g}$ at time of the experimental protocol. Rats were housed at the institutional animal facilities at the University of Alabama at Birmingham in temperature- and humiditycontrolled rooms with a 12-hour light/dark cycle. Experiments were conducted during the light period. Rats had free access to water and food (7917 Irradiated NIH-31 Mouse/Rat diet, 0.8\% NaCl; Envigo).

Surgical Procedure. Female $\mathrm{ET}_{\mathrm{B}}$ def rats and TG littermates were surgically prepared for acute intramedullary infusion experiments as detailed in our previous studies (Gohar et al., 2016a, 2017). Briefly, rats were anesthetized by intraperitoneal injections of thiobutabarbitone (Inactin hydrate, $100 \mathrm{mg} / \mathrm{kg}$ per milliliter, catalog number T133; Sigma-Aldrich Co., St. Louis, MO). The trachea was cannulated with polyethylene tubing (PE-205) to facilitate free breathing. The left femoral vein was cannulated with a PE-50 catheter for intravenous supplementation of $3 \%$ bovine serum albumin (catalog number A7906; Sigma-Aldrich Co.) in phosphate-buffered saline (catalog number 2810305; MP Biomedicals, Irvine, CA) at a rate of $1.2 \mathrm{ml} / \mathrm{h}$ to compensate for fluid loss and maintain euvolemia. Then, the left femoral artery was cannulated with a PE-50 catheter for blood pressure recording, after which a midline incision was made and the left ureter was cannulated by a PE-10 catheter to collect urine. Finally, $5 \mathrm{~mm}$ of stretched PE-10 catheter was inserted into the left kidney and positioned to deliver fluids at the outer-inner medullary junction at a rate of $0.5 \mathrm{ml} / \mathrm{h}$. After surgery, the animals were allowed to equilibrate for 60 minutes before baseline urine collection. At the end of each experiment, the kidney was dissected to confirm the proper positioning of the catheter within the renal medullary interstitium. Surgeries were performed on a heated surgical table to avoid hypothermia. In separate experiments, the female SD rats underwent surgical procedures identical to those described above. Importantly, the intramedullary infusion technique we used has been shown to induce localized effects in the renal medulla, not the renal cortex (Stec et al., 1997; Speed and Hyndman, 2016).

Blood Pressure Measurement. Blood pressure was recorded in anesthetized animals via femoral artery catheterization. The catheter was connected to a blood pressure transducer (DPT-200, Deltran II; Utah Medical Products Ltd., Midvale, UT) with an output to PowerLab analog-to-digital converter (4/35; ADInstruments, Colorado Springs, CO) via a Quad Bridge Amplifier (FE224; ADInstruments). LabChart software version 7 was used to record and analyze blood pressure. Blood pressure data are presented as mean arterial pressure (MAP).

Experimental Protocol. Our experimental protocol is depicted in Fig. 1A. After the 60-minute postsurgical stabilization period, urine was collected over a 20 -minute baseline period, and vehicle $(0.02 \%$ DMSO in saline) for the selective GPER1 agonist G1 was infused into the renal medulla (DMSO, catalog number D8418; Sigma-Aldrich Co.). Then, G1 (5 pmol/kg per minute, catalog number 41004001; Sandia Biotec Inc. Albuquerque, NM) was infused into the renal medulla for 40 minutes (Fig. 1A). This intramedullary dose of G1 promotes natriuresis in female SD rats (Gohar et al., 2020). After 20 minutes of G1 infusion, a 20-minute urine sample was collected while G1 was still being infused to the renal medulla (Fig. 1A). Urine volume was determined gravimetrically. To pharmacologically inhibit the $\mathrm{ET}_{\mathrm{A}}$ receptor, $\mathrm{ET}_{\mathrm{B}}$ def rats were treated with an intravenous bolus injection of the $\mathrm{ET}_{\mathrm{A}}$ receptor antagonist ABT-627 $(5 \mathrm{mg} / \mathrm{kg}$; AbbVie Inc., Abbott Park, IL; $n=5)$ or vehicle $(n=6) 30$ minutes before the end of the postsurgical stabilization period (Fig. 1A). Animal groups used are depicted in Fig. 1B. To pharmacologically inhibit ET receptors, SD rats were treated with an intravenous bolus injection of ABT-627 (5 $\mathrm{mg} / \mathrm{kg} ; n=8$ ) and/or the $\mathrm{ET}_{\mathrm{B}}$ receptor antagonist A-192621 (10 mg/kg; PepTech Corp., Bedford, MA; $n=10$ and 9, respectively) 30 minutes before the end of the postsurgical stabilization period (Fig. 1A). These doses of ABT-627 and A-192621 have been shown to elicit efficient pharmacologic blockade of $\mathrm{ET}_{\mathrm{A}}$ and $\mathrm{ET}_{\mathrm{B}}$, respectively, for this experimental duration (Gohar et al., 2016a), as ABT-627 and A-192621 have half-lives of 6 and 5 hours, respectively, in rats 
A

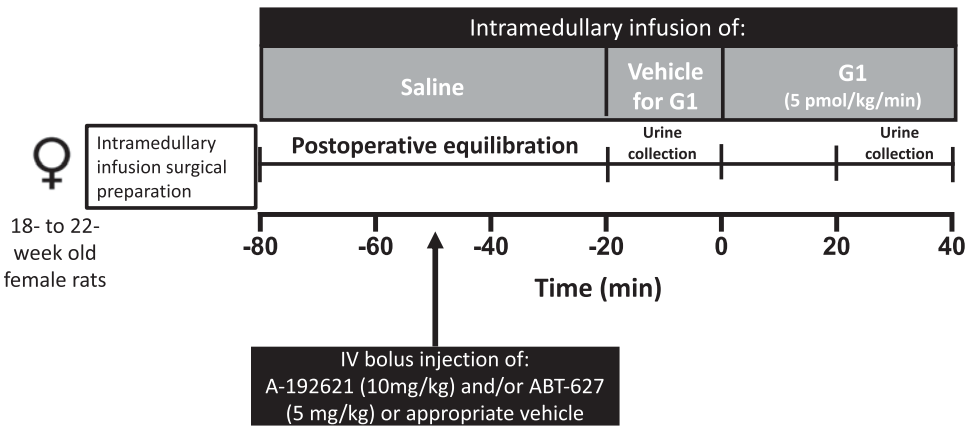

B

\begin{tabular}{|l|l|}
\hline \multicolumn{2}{|c|}{ Animal groups } \\
\hline \multicolumn{1}{|c|}{ TG and $\mathrm{ET}_{\mathrm{B}}$ def rat groups } & SD rat groups \\
\hline 1. $\mathrm{TG}+$ vehicle & 1. $\mathrm{SD}+$ vehicle \\
2. $\mathrm{ET}_{\mathrm{B}}$ def + vehicle & 2. $\mathrm{SD}+\mathrm{ET}_{\mathrm{B}}$ receptor antagonist (ABT-627) \\
3. $\mathrm{ET}_{\mathrm{B}}$ def $+\mathrm{ET}_{\mathrm{A}}$ receptor antagonist (A-192621) & 3. $\mathrm{SD}+\mathrm{ET}_{\mathrm{A}}$ receptor antagonist (A-192621) \\
& 4. $\mathrm{SD}+$ antagonists for $\mathrm{ET}_{\mathrm{A}}$ and $\mathrm{ET}_{\mathrm{B}}$ receptors
\end{tabular}

Fig. 1. Schematic presentation of the experimental timeline (A) and animal groups (B) used in intramedullary infusion experiments.
(Wessale et al., 2002). A separate experimental group of SD $(n=11)$ and TG rats $(n=9)$ received an intravenous bolus injection of vehicle $(0.5 \mathrm{ml} / \mathrm{kg})$ and served as controls (Fig. 1B). The vehicle used to solubilize ABT-627 and A-192621 was composed of $60 \%$ polyethylene glycol 400 (catalog number 91893; Sigma-Aldrich Co.) and 25\% ethanol (molecular-grade, catalog number E7023; Sigma-Aldrich Co.) in saline. Urine samples were stored at $-80^{\circ} \mathrm{C}$ until further analysis.

Of note, G1 is a highly selective agonist for GPER1 and displays no activity against classic estrogen receptors (Bologa et al., 2006; Albanito et al., 2007) or a panel of 25 other G protein-coupled receptors (Blasko et al., 2009). Moreover, the physiologic actions of G1 are not evident in GPER1-knockout mice (Haas et al., 2009; Liu et al., 2009; Wang et al., 2009).

Measurement of Urinary Electrolytes. Urine $\mathrm{Na}^{+}$and $\mathrm{K}^{+}$ concentrations were determined using an atomic absorption spectrometer (iCE 3000 series paired with a CETAC ASX-520 AutoSampler; ThermoFisher Scientific, Waltham, MA) in the flame photometry mode.

Statistics. Comparisons between groups were analyzed by a repeated-measures two-way ANOVA followed by Dunnett's post hoc tests. Parameters measured during the first 20 minutes of G1 infusion were included in the statistical analysis. For clarity in data presentation, only responses during the second 20 minutes and not the first 20 minutes of $\mathrm{G} 1$ infusion are presented in the figures. Values are presented as means \pm S.E.M. $P$ values less than 0.05 were considered statistically significant. Statistical analysis was performed using GraphPad Prism version 8.

\section{Results}

$\mathbf{E T}_{\mathbf{B}}$-Deficient Rats. Intramedullary infusion of G1, the selective GPER1 agonist, increased the urinary $\mathrm{Na}^{+}$excretion by $97 \% \pm 19 \%$ and $126 \% \pm 36 \%$ relative to baseline in TG control rats and $\mathrm{ET}_{\mathrm{B}}$ def rats, respectively (Fig. 2A). Urine flow also increased in response to G1 infusion in female TG control rats and $\mathrm{ET}_{\mathrm{B}}$ def rats (Fig. 2B. In both groups, urinary $\mathrm{K}^{+}$excretion remained relatively stable during the infusion (Fig. 2C). As previously reported, MAP was higher in $\mathrm{ET}_{\mathrm{B}}$ def rats than in TG littermates at baseline and did not change after G1 infusion in either group (Fig. 3).

Pretreatment of $\mathrm{ET}_{\mathrm{B}}$ def rats with the $\mathrm{ET}_{\mathrm{A}}$ receptor antagonist ABT-627 prevented the G1-induced increase in urinary $\mathrm{Na}^{+}$excretion and urine flow (Fig. 2, A and B) but did not affect urinary $\mathrm{K}^{+}$excretion (Fig. 2C). Pretreatment of $\mathrm{ET}_{\mathrm{B}}$ def rats with ABT-627 also caused a slight decrease in MAP that did not reach statistical significance (Fig. 3) but did eliminate the difference in MAP between $\mathrm{ET}_{\mathrm{B}}$ def and TG controls.

Sprague-Dawley Rats. To examine the effects of blocking either $\mathrm{ET}_{\mathrm{A}}$ or $\mathrm{ET}_{\mathrm{B}}$ receptor alone, we conducted similar experiments in female SD rats. Intramedullary infusion of G1 in SD rats increased urinary $\mathrm{Na}^{+}$excretion by $70 \% \pm$ $24 \%$ relative to baseline (Fig. $4 \mathrm{~A}$ ), which was similar to our recent study (Gohar et al., 2020). Urine flow was also increased in response to G1 infusion in SD rats (Fig. 4B). No significant differences were observed in urinary $\mathrm{K}^{+}$excretion or MAP during G1 infusion in these rats when compared with corresponding baseline values (Fig. 4C; Fig. 5). Pretreatment of the SD rats with either ABT-627 or A-192621 did not alter the G1-induced increase in urinary $\mathrm{Na}^{+}$excretion or urine flow (Fig. 4, A and B). However, pretreatment with ABT-627 and A192621 simultaneously completely abolished the natriuretic and diuretic response to G1 infusion (Fig. 4, A and B). G1 elicited a significant overall effect on urinary $\mathrm{K}^{+}$excretion in $\mathrm{SD}$ rats (Fig. 4C). However, there was no significant increase in comparison with corresponding baseline values in SD rats pretreated with either ET-1 receptor antagonist alone or in combination (Fig. 4C). Similar to the increase in MAP observed in $\mathrm{ET}_{\mathrm{B}}$ def rats, treatment with A-192621 alone resulted in an increase in MAP that was stable across the experimental period (Fig. 5). However, this increase in MAP did not occur after pretreatment with ABT-627 and A-192621 simultaneously (Fig. 5). In fact, pretreatment with ABT-627 alone or in combination with A-192621 resulted in a small but statistically significant decline in MAP during G1 infusion (Fig. 5).

\section{Discussion}

In this study, we sought to elucidate the contribution of $\mathrm{ET}_{\mathrm{A}}$ and $\mathrm{ET}_{\mathrm{B}}$ receptors as downstream mediators of renal medullary GPER1-induced natriuresis. Overall, we provide genetic and pharmacologic evidence for a functional role of these receptors within the renal medulla in mediating 
A

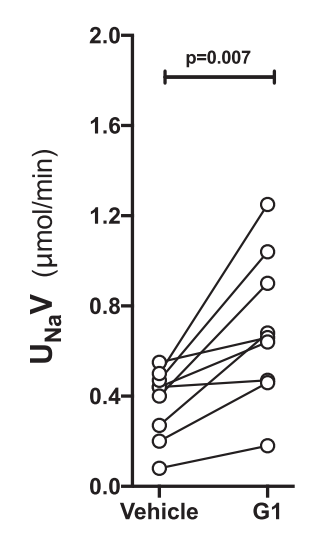

B
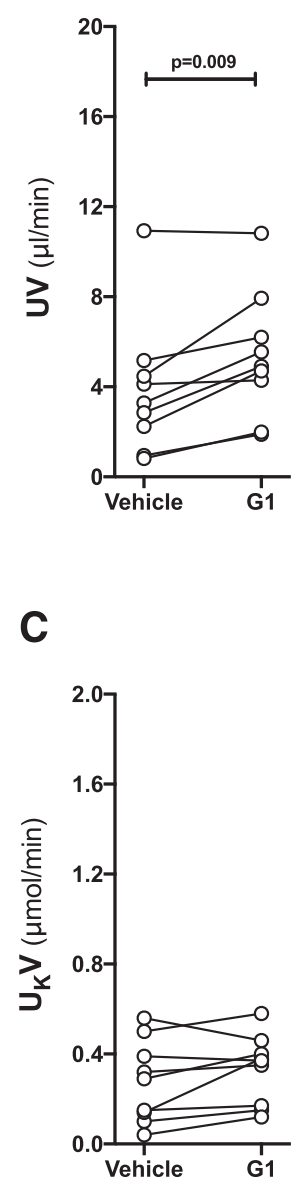
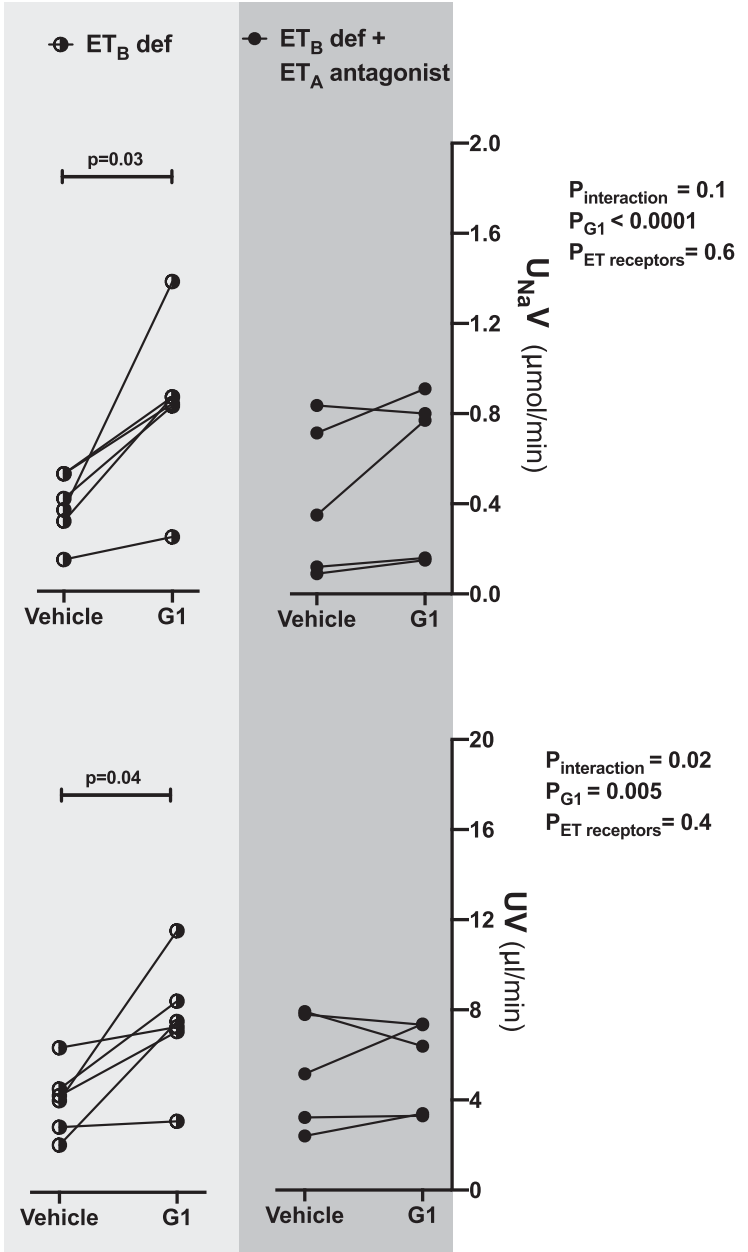

Fig. 2. Blockade of $\mathrm{ET}_{\mathrm{A}}$ receptor abolished the natriuretic response to renal medullary GPER1 activation in female $\mathrm{ET}_{\mathrm{B}}$ def rats. Urinary $\mathrm{Na}^{+}$excretion $\left(\mathrm{U}_{\mathrm{Na}} \mathrm{V}\right)(\mathrm{A})$, urine flow (UV) (B), and urinary $\mathrm{K}^{+}$excretion $\left(\mathrm{U}_{\mathrm{K}} \mathrm{V}\right)$ (C) were measured during two 20-minute urine collection periods in anesthetized female $\mathrm{ET}_{\mathrm{B}}$ def rats or TG control rats: at baseline during the intramedullary infusion of vehicle and 20 minutes after the infusion of the GPER1 agonist G1 (5 $\mathrm{pmol} / \mathrm{kg}$ per minute) was initiated. $\mathrm{ET}_{\mathrm{A}}$ receptor blockade was achieved by intravenous bolus injections of ABT-627 $(5 \mathrm{mg} / \mathrm{kg}) 30$ minutes before the beginning of the baseline urine collection period; TG and $\mathrm{ET}_{\mathrm{B}}$ def controls received intravenous bolus injections of vehicle. Each line shows data for an individual animal. Statistical comparisons were performed by repeated-measures two-way ANOVA followed by Dunnett's post hoc tests.
GPER1-induced natriuresis. These results are compatible with previous evidence showing that $\mathrm{ET}_{\mathrm{A}}$ and $\mathrm{ET}_{\mathrm{B}}$ receptors promote water and $\mathrm{Na}^{+}$excretion (Ge et al., 2008; Boesen and Pollock, 2010).

In the present study, we demonstrated that activation of GPER1 within the medulla of the kidney of female SD rats evokes a natriuretic and a diuretic effect, consistent with our recent findings (Gohar et al., 2020). Notably, several studies have demonstrated that GPER1 activation ameliorates saltinduced cardiovascular and kidney damage (Jessup et al., 2010;
Lindsey et al., 2011; Liu et al., 2016). Specifically, GPER1 activation was shown to attenuate salt-induced cardiac remodeling (Jessup et al., 2010), vascular injury (Liu et al., 2016), and proteinuria (Lindsey et al., 2011) in mRen2.Lewis rats in a blood pressure-independent manner. The renoprotective actions of GPER1 activation were linked to decreased tubular oxidative stress and increased megalin-mediated protein reabsorption (Lindsey et al., 2011). However, the relationship between GPER1 activation and $\mathrm{Na}^{+}$homeostasis was not defined. Our recently published study showed that renal 


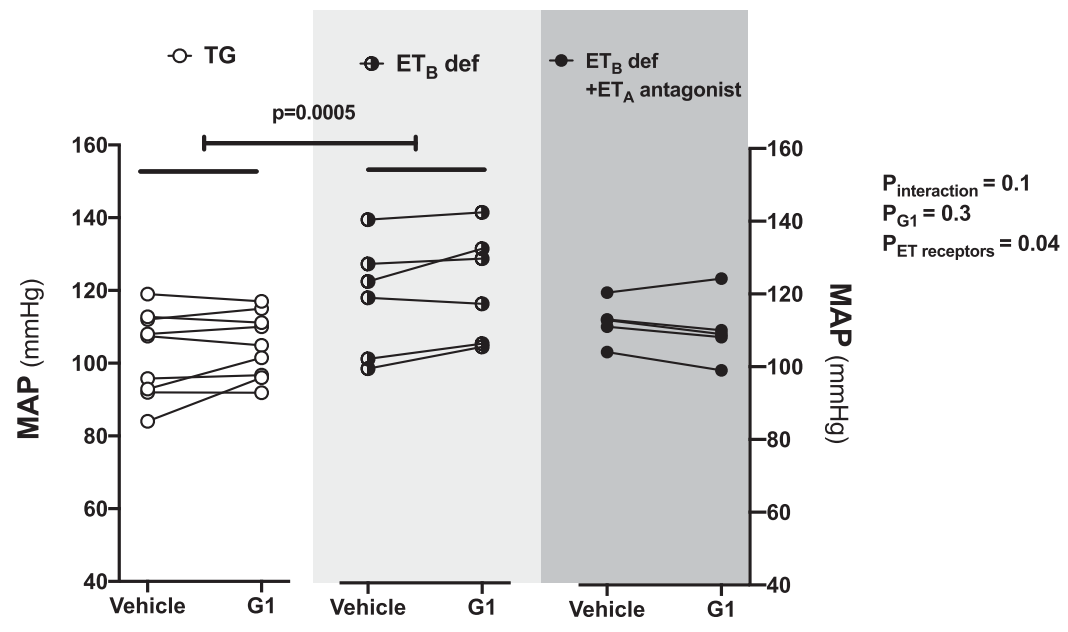

Fig. 3. Effect of $\mathrm{ET}_{\mathrm{A}}$ receptor blockade on blood pressure during renal medullary GPER1 activation in female $\mathrm{ET}_{\mathrm{B}}$ def rats. MAP was measured during two 20-minute urine collection periods in anesthetized female $\mathrm{ET}_{\mathrm{B}}$ def rats or TG control rats: at baseline during the intramedullary infusion of vehicle and 20 minutes after the infusion of the GPER1 agonist G1 (5 pmol/kg per minute) was initiated. $\mathrm{ET}_{\mathrm{A}}$ receptor blockade was achieved by intravenous bolus injection of ABT-627 $(5 \mathrm{mg} / \mathrm{kg}) 30$ minutes before the beginning of the baseline urine collection period in female $\mathrm{ET}_{\mathrm{B}}$ def rats; $\mathrm{TG}$ and $\mathrm{ET}_{\mathrm{B}}$ def controls received intravenous bolus injections of vehicle. Each line shows data for an individual animal. Statistical comparisons were performed by repeated-measures two-way ANOVA followed by Dunnett's post hoc tests. medullary GPER1 functions as a novel female-specific pronatriuretic factor via an ET-1-dependent signaling pathway. We also revealed that the mRNA expression of ET-1 and the $\mathrm{ET}_{\mathrm{A}}$ and $\mathrm{ET}_{\mathrm{B}}$ receptors is diminished in female GPER1knockout mice compared with wild-type controls (Gohar et al., 2020). This effect was not evident in male mice (Gohar et al., 2020).

In the current study, we found that genetic deficiency or pharmacologic blockade of $\mathrm{ET}_{\mathrm{B}}$ receptors does not attenuate the G1-induced natriuresis observed in female SD rats, suggesting that the pronatriuretic actions of GPER1 can be mediated via $\mathrm{ET}_{\mathrm{A}}$ receptors. Hence, the inhibition of GPER1-induced natriuresis requires concomitant antagonism of $\mathrm{ET}_{\mathrm{A}}$ and $\mathrm{ET}_{\mathrm{B}}$ receptors in female rats. Nakano and Pollock (2009) demonstrated that $\mathrm{ET}_{\mathrm{A}}$ receptor contributes to ET-1-dependent natriuresis in female rats, and it has been shown that $\mathrm{ET}_{\mathrm{A}}$ and $\mathrm{ET}_{\mathrm{B}}$ receptors work synergistically to promote water and $\mathrm{Na}^{+}$excretion (Ge et al., 2008; Boesen and Pollock, 2010). These latter findings are consistent with our present findings, suggesting that $\mathrm{ET}_{\mathrm{A}}$ and $\mathrm{ET}_{\mathrm{B}}$ receptors help efficient excretion of salt and water.

Our observation that $\mathrm{ET}_{\mathrm{A}}$ or $\mathrm{ET}_{\mathrm{B}}$ receptor can mediate the G1 natriuretic effect alternatively under conditions of loss of the other receptor subtype is interesting, suggesting the capability of one ET receptor to compensate for the loss of function of the other receptor. However, this observation does not negate the possibility that one receptor may be solely or predominantly mediating GPER1 natriuretic action under normal physiologic conditions when both ET receptors are functional.

This interaction between $\mathrm{ET}_{\mathrm{A}}$ and $\mathrm{ET}_{\mathrm{B}}$ receptors has also been documented within the vasculature (White et al., 1993; Seo et al., 1994; Inscho et al., 2005). Inscho et al. (2005) showed that both $\mathrm{ET}_{\mathrm{A}}$ and $\mathrm{ET}_{\mathrm{B}}$ receptors contribute to $\mathrm{ET}-1-$ induced vasoconstriction of afferent arterioles, highlighting a possible interaction between $\mathrm{ET}_{\mathrm{A}}$ and $\mathrm{ET}_{\mathrm{B}}$ receptors in the control of afferent arteriolar vascular tone. Similarly, ET-1 actions via $\mathrm{ET}_{\mathrm{B}}$ and possibly $\mathrm{ET}_{\mathrm{A}}$ receptors contribute to the blunted renal autoregulation in salt-loaded rats (Fellner et al., 2015). It has also been demonstrated that $\mathrm{ET}_{\mathrm{A}}$ receptor expression in the lung is diminished in $\mathrm{ET}_{\mathrm{B}}$ knockout mice (Kuc et al., 2006). Notably, fluorescence resonance energy transfer experiments demonstrated that $\mathrm{ET}_{\mathrm{A}}$ and $\mathrm{ET}_{\mathrm{B}}$ receptors exist as constitutive homodimers and heterodimers (Gregan et al., 2004a,b).
In addition, Kapsokalyvas et al. (2014) provided imaging evidence for $\mathrm{ET}_{\mathrm{A}}$ and $\mathrm{ET}_{\mathrm{B}}$ receptor heterodimerization in rat mesenteric resistance arteries. Further experiments are required to identify whether heterodimers exist in epithelial cells and whether such dimers have relevance to the functional interaction between $\mathrm{ET}_{\mathrm{A}}$ and $\mathrm{ET}_{\mathrm{B}}$ receptors.

We demonstrated that $\mathrm{ET}_{\mathrm{A}}$ receptor blockade alone does not mitigate G1-induced natriuresis in female SD rats. However, whether the GPER1/ET $\mathrm{E}_{\mathrm{A}}$ receptor-mediated natriuretic effect is a compensatory mechanism that occurs only under conditions of $\mathrm{ET}_{\mathrm{B}}$ receptor dysfunction remains unclear. The observation that both $\mathrm{ET}_{\mathrm{A}}$ and $\mathrm{ET}_{\mathrm{B}}$ receptors contribute to mediating the natriuretic response to GPER1, which is endogenously activated by estradiol in females, may have important implications for therapeutic use of dual $\mathrm{ET}_{\mathrm{A}}$ and $\mathrm{ET}_{\mathrm{B}}$ antagonists in female patients.

Changes in blood pressure and consequently pressure natriuresis do not appear to account for G1 natriuretic actions. We found that pharmacologic blockade of $\mathrm{ET}_{\mathrm{A}}$ in the presence or absence of $\mathrm{ET}_{\mathrm{B}}$ receptor blockade in $\mathrm{SD}$ rats decreases blood pressure before and after GPER1 activation. Importantly, GPER1-induced natriuresis was still evident despite the lower blood pressure produced by the $\mathrm{ET}_{\mathrm{A}}$ antagonist. We also found that genetic deficiency or pharmacologic blockade of $\mathrm{ET}_{\mathrm{B}}$ receptors elevates blood pressure, similar to previous observations (Gariepy et al., 2000; Pollock and Pollock, 2001; Ge et al., 2006). Furthermore, G1 evoked a natriuretic action in animals with elevated blood pressure due to loss of $\mathrm{ET}_{\mathrm{B}}$ receptor function. Whether GPER1-induced natriuresis is evident in other experimental models of hypertension remains to be determined.

The localization of GPER1 and $\mathrm{ET}_{\mathrm{A}}$ and $\mathrm{ET}_{\mathrm{B}}$ receptors is also appropriate to support the crosstalk we observed between these receptors in the kidney. Multiple studies have shown that GPER1 is expressed in kidney cells (Hazell et al., 2009; Lindsey et al., 2011; Cheng et al., 2014; Li et al., 2014; Cheema et al., 2015). Earlier studies in which Davidoff et al. (1980) tested the binding capacity and affinity for $\left[{ }^{3} \mathrm{H}\right]$ estradiol in the cytosolic fraction of rat renal homogenates revealed radioactivity within the distal part of the tubule, specifically in the inner medullary collecting duct cells (Davidoff et al., 1980). In line with this finding, immunohistology revealed that GPER1 is expressed in the rat renal inner medulla (Hazell et al., 2009; Gohar et al., 2020). Similarly, studies with radioactively 
A

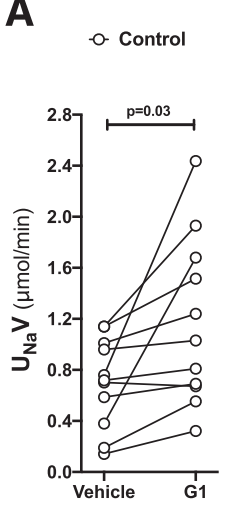

B

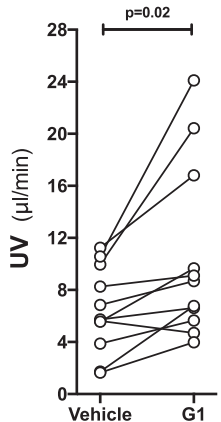

C

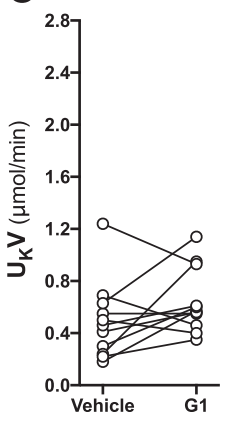

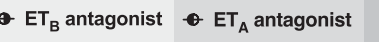

$\mathrm{ET}_{\mathrm{A}+\mathrm{B}}$ antagonists
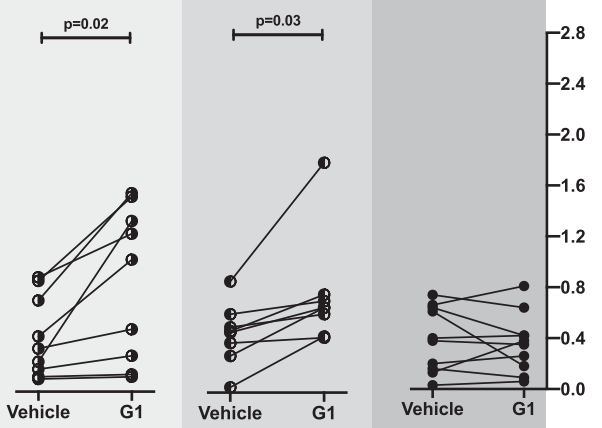

$P_{\text {interaction }}=0.02$

$P_{\mathrm{G} 1}<0.0001$

$P_{\mathrm{ET} \text { receptors }}=0.02$

Fig. 4. Combined blockade of $\mathrm{ET}_{\mathrm{A}}$ and $\mathrm{ET}_{\mathrm{B}}$ receptors abolished the natriuretic response to renal medullary GPER1 activation in female SD rats. Urinary $\mathrm{Na}^{+}$excretion $\left(\mathrm{U}_{\mathrm{Na}} \mathrm{V}\right)(\mathrm{A})$, urine flow (UV) (B), and urinary $\mathrm{K}^{+}$excretion $\left(\mathrm{U}_{\mathrm{K}} \mathrm{V}\right)(\mathrm{C})$ were measured during two 20-minute urine collection periods in anesthetized female SD rats: at baseline during the intramedullary infusion of vehicle and 20 minutes after intermedullary infusion of the GPER1 agonist G1 (5 pmol/kg per minute) was initiated. $\mathrm{ET}_{\mathrm{A}}$ and $\mathrm{ET}_{\mathrm{B}}$ receptor blockade was achieved by intravenous bolus injection of ABT-627 (5 mg/kg) and A-192621 (10 mg/kg), respectively, 30 minutes before the beginning of the baseline urine collection period; controls received intravenous bolus injections of vehicle. Each line shows data for an individual animal. Statistical comparisons were performed by repeatedmeasures two-way ANOVA followed by Dunnett's post hoc tests.

labeled ET-1 showed ET-1 binding primarily in the renal medulla (Davenport et al., 1989), and a high density of ET receptors was detected in inner medullary collecting duct cells
(Kohan et al., 1992). Overall, our study identifies a novel role for rapid estrogenic signaling as an upstream regulator of an $\mathrm{ET}-1 / \mathrm{ET}_{\mathrm{A}} / \mathrm{ET}_{\mathrm{B}}$ pronatriuretic signaling system, supporting

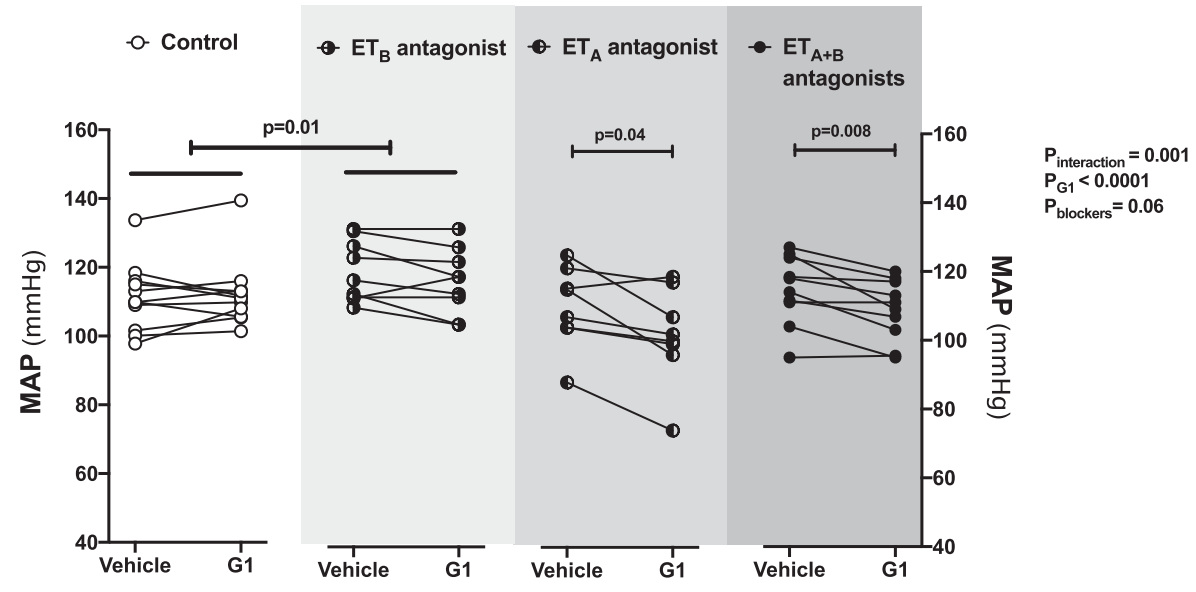

Fig. 5. Effect of $\mathrm{ET}_{\mathrm{A}}$ and/or $\mathrm{ET}_{\mathrm{B}}$ receptor blockade on blood pressure during renal medullary GPER1 activation in female SD rats. MAP was measured during two 20-minute urine collection periods in anesthetized female SD rats: at baseline during the intramedullary infusion of vehicle and 20 minutes after intermedullary infusion of the GPER1 agonist G1 (5 pmol/kg per minute) was initiated. $\mathrm{ET}_{\mathrm{A}}$ and $\mathrm{ET}_{\mathrm{B}}$ receptor blockade was achieved by intravenous bolus injection of ABT-627 $(5 \mathrm{mg} / \mathrm{kg})$ and A-192621 (10 mg/kg), respectively, 30 minutes before the beginning of the baseline urine collection period; controls received intravenous bolus injections of vehicle. Each line shows data for an individual animal. Statistical comparisons were performed by repeated-measures two-way ANOVA followed by Dunnett's post hoc tests. 
the importance of the intrarenal ET-1 system in renal $\mathrm{Na}^{+}$ handling, particularly in females.

The regulation of natriuresis is highly integrated and involves many neural, vascular, and tubular signaling events within the kidney. We previously demonstrated that G1 downregulates $\mathrm{Na}^{+} / \mathrm{K}^{+}$ATPase activity in the renal outer medulla (Gohar et al., 2020). However, we do not know the contribution of the vascular and neuronal components to GPER1-induced natriuresis, if any. Evidence points to a vasodilatory response to GPER1 activation in multiple extrarenal vascular beds (Haynes et al., 2002; Broughton et al., 2010; Lindsey et al., 2014; Tropea et al., 2015; Peixoto et al., 2017; Fredette et al., 2018). Similarly, the GPER1 agonist, G1, induces a vasodilation in isolated perfused rat kidneys preconstricted with phenylephrine (Kurt and Buyukafsar, 2013). In contrast, G1 evokes a vasoconstrictor response in the isolated perfused rat kidney under basal renal perfusion pressure (Kurt and Buyukafsar, 2013). Importantly, renal medullary GPER1 activation did not change blood flow in the medulla of the kidney (Gohar et al., 2020). Despite reports that GPER1 can modulate neuronal function, its role in regulating renal nerves is not clear. Li et al. (2016) provided evidence that GPER1 inhibits colonic motility by enhancing nitric oxide release from nitrergic nerves. GPER1 also appears to exert an inhibitory effect on neuronal apoptosis in the hippocampus (Han et al., 2019). Furthermore, GPER1 activation induces bradycardic effects via activation of cardiac parasympathetic neurons (Brailoiu et al., 2013). Additional studies are required to determine the contribution of renal nerves, if any, to GPER1-dependent natriuresis and how that relates to hypertension.

Previous studies have shown that systemic GPER1 activation lowers blood pressure in ovariectomized SD rats (Gohar et al., 2020) and mRen2.Lewis rats (Lindsey et al., 2009). Further, natriuresis evoked by renal medullary GPER1 activation is evident after ovariectomy (Gohar et al., 2020). Indeed, ovariectomy did not impact GPER1 protein expression in the renal medulla (Gohar et al., 2020). Of note, ovariectomy increased the mRNA expression of $\mathrm{ET}_{\mathrm{A}}$ and $\mathrm{ET}_{\mathrm{B}}$ in renal inner medulla (Gohar et al., 2016b). However, the contribution of ET receptors to GPER1-induced natriuresis under conditions of sex hormonal deficiency remains to be determined.

Collectively, we have demonstrated that G1 activates the GPER1/ET $\mathrm{A}_{\mathrm{A}} / \mathrm{ET}_{\mathrm{B}}$ axis, which in turn triggers natriuresis, suggesting that targeting GPER1 may be a useful approach to maintaining cardiovascular health in women. The question of whether GPER1 activation triggers an increase in ET-1 release and/or production remains to be answered. The effects of GPER1 activity on transport activity related to $\mathrm{Ca}^{2+}$ influx and specific renal $\mathrm{Na}^{+}$transporters need to be investigated. Further research is also required to determine the functional significance of the interaction between GPER1 and ET receptors with regard to $\mathrm{Na}^{+}$balance and hypertension and to expand our understanding of GPER1 actions on renal electrolyte handling and salt sensitivity.

\section{Acknowledgments}

The authors would like to thank Rawan N. Almutlaq for technical assistance with atomic absorption measurement.

\section{Authorship Contributions}

Participated in research design: Gohar, Pollock
Conducted experiments: Gohar.

Performed data analysis: Gohar.

Wrote or contributed to the writing of the manuscript: Gohar, Pollock.

\section{References}

Albanito L, Madeo A, Lappano R, Vivacqua A, Rago V, Carpino A, Oprea TI, Prossnitz ER, Musti AM, Andò S, et al. (2007) G protein-coupled receptor 30 (GPR30) mediates gene expression changes and growth response to 17betaestradiol and selective GPR30 ligand G-1 in ovarian cancer cells. Cancer Res 67: 1859-1866

Bairey Merz CN, Andersen HS, and Shufelt CL (2015) Gender, cardiovascular disease, and the sexism of obesity. J Am Coll Cardiol 66:1958-1960.

Benjamin EJ, Virani SS, Callaway CW, Chamberlain AM, Chang AR, Cheng S, Chiuve SE, Cushman M, Delling FN, Deo R, et al.; American Heart Association Council on Epidemiology and Prevention Statistics Committee and Stroke Statistics Subcommittee (2018) Heart disease and stroke statistics-2018 update: a report from the American heart association. Circulation 137:e67-e492.

Blasko E, Haskell CA, Leung S, Gualtieri G, Halks-Miller M, Mahmoudi M, Dennis MK, Prossnitz ER, Karpus WJ, and Horuk R (2009) Beneficial role of the GPR30 agonist G-1 in an animal model of multiple sclerosis. J Neuroimmunol 214:67-77. Boesen EI (2015) Endothelin receptors, renal effects and blood pressure. Curr Opin Pharmacol 21:25-34.

Boesen EI and Pollock DM (2010) Cooperative role of ETA and ETB receptors in mediating the diuretic response to intramedullary hyperosmotic $\mathrm{NaCl}$ infusion. $\mathrm{Am}$ J Physiol Renal Physiol 299:F1424-F1432.

Bologa CG, Revankar CM, Young SM, Edwards BS, Arterburn JB, Kiselyov AS, Parker MA, Tkachenko SE, Savchuck NP, Sklar LA, et al. (2006) Virtual and biomolecular screening converge on a selective agonist for GPR30. Nat Chem Biol 2:207-212.

Brailoiu GC, Arterburn JB, Oprea TI, Chitravanshi VC, and Brailoiu E (2013) Bradycardic effects mediated by activation of $\mathrm{G}$ protein-coupled estrogen receptor in rat nucleus ambiguus. Exp Physiol 98:679-691.

Broughton BR, Miller AA, and Sobey CG (2010) Endothelium-dependent relaxation by $\mathrm{G}$ protein-coupled receptor 30 agonists in rat carotid arteries. Am J Physiol Heart Circ Physiol 298:H1055-H1061.

Chang Y, Han Z, Zhang Y, Zhou Y, Feng Z, Chen L, Li X, Li L, and Si JQ (2019) G protein-coupled estrogen receptor activation improves contractile and diastolic functions in rat renal interlobular artery to protect against renal ischemia reperfusion injury. Biomed Pharmacother 112:108666.

Cheema MU, Irsik DL, Wang Y, Miller-Little W, Hyndman KA, Marks ES, Frøkiær J, Boesen EI, and Norregaard R (2015) Estradiol regulates AQP2 expression in the collecting duct: a novel inhibitory role for estrogen receptor $\alpha$. Am J Physiol Renal Physiol 309:F305-F317.

Cheng SB, Dong J, Pang Y, LaRocca J, Hixon M, Thomas P, and Filardo EJ (2014) Anatomical location and redistribution of $\mathrm{G}$ protein-coupled estrogen receptor-1 during the estrus cycle in mouse kidney and specific binding to estrogens but not aldosterone. Mol Cell Endocrinol 382:950-959.

Davenport AP, Nunez DJ, and Brown MJ (1989) Binding sites for 125I-labelled endothelin-1 in the kidneys: differential distribution in rat, pig and man demonstrated by using quantitative autoradiography. Clin Sci (Lond) 77:129-131.

Davidoff M, Caffier H, and Schiebler TH (1980) Steroid hormone binding receptors in the rat kidney. Histochemistry 69:39-48.

Dhaun N and Webb DJ (2008) Endothelin-receptor antagonism: the future is bright. Lancet 371:2061-2062.

Elijovich F, Weinberger MH, Anderson CA, Appel LJ, Bursztyn M, Cook NR, Dart RA, Newton-Cheh CH, Sacks FM, and Laffer CL; American Heart Association Professional and Public Education Committee of the Council on Hypertension; Council on Functional Genomics and Translational Biology; and Stroke Council (2016) Salt sensitivity of blood pressure: a scientific statement from the American heart association. Hypertension 68: $7-\mathrm{e} 46$.

Fellner RC, Guan Z, Cook AK, Pollock DM, and Inscho EW (2015) Endothelin contributes to blunted renal autoregulation observed with a high-salt diet. Am J Physiol Renal Physiol 309:F687-F696.

Fredette NC, Meyer MR, and Prossnitz ER (2018) Role of GPER in estrogendependent nitric oxide formation and vasodilation. J Steroid Biochem Mol Biol 176: 65-72.

Gariepy CE, Ohuchi T, Williams SC, Richardson JA, and Yanagisawa M (2000) Saltsensitive hypertension in endothelin-B receptor-deficient rats. J Clin Invest 105 925-933.

Gariepy CE, Williams SC, Richardson JA, Hammer RE, and Yanagisawa M (1998) Transgenic expression of the endothelin-B receptor prevents congenital intestinal aganglionosis in a rat model of Hirschsprung disease. J Clin Invest 102:1092-1101.

Ge Y, Bagnall A, Stricklett PK, Strait K, Webb DJ, Kotelevtsev Y, and Kohan DE (2006) Collecting duct-specific knockout of the endothelin B receptor causes hypertension and sodium retention. Am J Physiol Renal Physiol 291:F1274-F1280.

Ge Y, Bagnall A, Stricklett PK, Webb D, Kotelevtsev Y, and Kohan DE (2008) Combined knockout of collecting duct endothelin A and B receptors causes hypertension and sodium retention. Am J Physiol Renal Physiol 295:F1635-F1640.

Gohar EY, Daugherty EM, Aceves JO, Sedaka R, Obi IE, Allan JM, Soliman RH, Jin C, De Miguel C, Lindsey SH, et al. (2020) Evidence for G-protein-coupled estrogen receptor as a pronatriuretic factor. J Am Heart Assoc 9:e015110.

Gohar EY, Kasztan M, Becker BK, Speed JS, and Pollock DM (2017) Ovariectomy uncovers purinergic receptor activation of endothelin-dependent natriuresis. Am $J$ Physiol Renal Physiol 313:F361-F369.

Gohar EY, Speed JS, Kasztan M, Jin C, and Pollock DM (2016a) Activation of purinergic receptors (P2) in the renal medulla promotes endothelin-dependent natriuresis in male rats. Am J Physiol Renal Physiol 311:F260-F267. 
Gohar EY, Yusuf C, and Pollock DM (2016b) Ovarian hormones modulate endothelin A and B receptor expression. Life Sci 159:148-152.

Gregan B, Jürgensen J, Papsdorf G, Furkert J, Schaefer M, Beyermann M, Rosenthal W, and Oksche A (2004a) Ligand-dependent differences in the internalization of endothelin A and endothelin B receptor heterodimers. J Biol Chem 279: 27679-27687.

Gregan B, Schaefer M, Rosenthal W, and Oksche A (2004b) Fluorescence resonance energy transfer analysis reveals the existence of endothelin-A and endothelin-B receptor homodimers. J Cardiovasc Pharmacol 44 (Suppl 1):S30-S33.

Haas E, Bhattacharya I, Brailoiu E, Damjanović M, Brailoiu GC, Gao X, MuellerGuerre L, Marjon NA, Gut A, Minotti R, et al. (2009) Regulatory role of G proteincoupled estrogen receptor for vascular function and obesity. Circ Res 104:288-291.

Hall JE, Granger JP, do Carmo JM, da Silva AA, Dubinion J, George E, Hamza S, Speed J, and Hall ME (2012) Hypertension: physiology and pathophysiology. Compr Physiol 2:2393-2442.

Han ZW, Chang YC, Zhou Y, Zhang H, Chen L, Zhang Y, Si JQ, and Li L (2019) GPER agonist G1 suppresses neuronal apoptosis mediated by endoplasmic reticulum stress after cerebral ischemia/reperfusion injury. Neural Regen Res 14 1221-1229.

Haynes MP, Li L, Russell KS, and Bender JR (2002) Rapid vascular cell responses to estrogen and membrane receptors. Vascul Pharmacol 38:99-108.

Hazell GG, Yao ST, Roper JA, Prossnitz ER, O'Carroll AM, and Lolait SJ (2009) Localisation of GPR30, a novel G protein-coupled oestrogen receptor, suggests multiple functions in rodent brain and peripheral tissues. $J$ Endocrinol 202:223-236.

Hocher B and Ehrenreich H (2002) ETB receptor deficiency causes salt-sensitive hypertension. J Mol Med (Berl) 80:747-749; author reply 750-752.

Inscho EW, Imig JD, Cook AK, and Pollock DM (2005) ETA and ETB receptors differentially modulate afferent and efferent arteriolar responses to endothelin. $\mathrm{Br}$ $J$ Pharmacol 146:1019-1026.

Jessup JA, Lindsey SH, Wang H, Chappell MC, and Groban L (2010) Attenuation of salt-induced cardiac remodeling and diastolic dysfunction by the GPER agonist G-1 in female mRen2.Lewis rats. PLoS One 5:e15433

Kapsokalyvas D, Schiffers PM, Maij N, Suylen DP, Hackeng TM, van Zandvoort MA, and De Mey JG (2014) Imaging evidence for endothelin ETA/ETB receptor heterodimers in isolated rat mesenteric resistance arteries. Life Sci 111:36-41.

Kilkenny C, Browne W, Cuthill IC, Emerson M, and Altman DG; NC3Rs Reporting Guidelines Working Group (2010) Animal research: reporting in vivo experiments: the ARRIVE guidelines. $\mathrm{Br}$ J Pharmacol 160:1577-1579.

Kohan DE (2011) Endothelin and collecting duct sodium and water transport. Contrib Nephrol 172:94-106

Kohan DE, Hughes AK, and Perkins SL (1992) Characterization of endothelin receptors in the inner medullary collecting duct of the rat. $J$ Biol Chem 267: 12336-12340.

Kohan DE, Inscho EW, Wesson D, and Pollock DM (2011) Physiology of endothelin and the kidney. Compr Physiol 1:883-919.

Kuc RE, Maguire JJ, and Davenport AP (2006) Quantification of endothelin receptor subtypes in peripheral tissues reveals downregulation of ET(A) receptors in ET(B)deficient mice. Exp Biol Med (Maywood) 231:741-745.

Kurt AH, Bozkus F, Uremis N, and Uremis MM (2016) The protective role of G protein-coupled estrogen receptor 1 (GPER-1) on methotrexate-induced nephrotoxicity in human renal epithelium cells. Ren Fail 38:686-692.

Kurt AH and Buyukafsar K (2013) Vasoconstriction induced by G1, a G-proteincoupled oestrogen receptor1 (GPER-1) agonist, in the isolated perfused rat kidney. Eur $J$ Pharmacol 702:71-78

Leifheit-Limson EC, D'Onofrio G, Daneshvar M, Geda M, Bueno H, Spertus JA, Krumholz HM, and Lichtman JH (2015) Sex differences in cardiac risk factors, perceived risk, and health care provider discussion of risk and risk modification among young patients with acute myocardial infarction: the VIRGO study. J Am Coll Cardiol 66:1949-1957.

Li Y, Xu J, Jiang F, Jiang Z, Liu C, Li L, Luo Y, Lu R, Mu Y, Liu Y, et al. (2016) G protein-coupled estrogen receptor is involved in modulating colonic motor function via nitric oxide release in C57BL/6 female mice. Neurogastroenterol Motil 28:432-442.

Li YC, Ding XS, Li HM, Zhang Y, and Bao J (2014) Role of G protein-coupled estrogen receptor 1 in modulating transforming growth factor- $\beta$ stimulated mesangial cell extracellular matrix synthesis and migration. Mol Cell Endocrinol 391:50-59.

Lindsey SH, Cohen JA, Brosnihan KB, Gallagher PE, and Chappell MC (2009) Chronic treatment with the $\mathrm{G}$ protein-coupled receptor 30 agonist $\mathrm{G}-1$ decreases blood pressure in ovariectomized mRen2.Lewis rats. Endocrinology 150:3753-3758.

Lindsey SH, Liu L, and Chappell MC (2014) Vasodilation by GPER in mesenteric arteries involves both endothelial nitric oxide and smooth muscle cAMP signaling. Steroids 81:99-102.
Lindsey SH, Yamaleyeva LM, Brosnihan KB, Gallagher PE, and Chappell MC (2011) Estrogen receptor GPR30 reduces oxidative stress and proteinuria in the saltsensitive female mRen2.Lewis rat. Hypertension 58:665-671.

Liu L, Kashyap S, Murphy B, Hutson DD, Budish RA, Trimmer EH, Zimmerman MA, Trask AJ, Miller KS, Chappell MC, et al. (2016) GPER activation ameliorates aortic remodeling induced by salt-sensitive hypertension. Am J Physiol Heart Circ Physiol 310:H953-H961.

Liu S, Le May C, Wong WP, Ward RD, Clegg DJ, Marcelli M, Korach KS, and Mauvais-Jarvis F (2009) Importance of extranuclear estrogen receptor-alpha and membrane $\mathrm{G}$ protein-coupled estrogen receptor in pancreatic islet survival. Diabetes 58:2292-2302.

Meyers KE and Sethna C (2013) Endothelin antagonists in hypertension and kidney disease. Pediatr Nephrol 28:711-720.

Moorhouse RC, Webb DJ, Kluth DC, and Dhaun N (2013) Endothelin antagonism and its role in the treatment of hypertension. Curr Hypertens Rep 15:489-496.

Nakano D and Pollock DM (2009) Contribution of endothelin A receptors in endothelin 1-dependent natriuresis in female rats. Hypertension 53:324-330.

Ostchega Y, Fryar CD, Nwankwo T, and Nguyen DT (2020) Hypertension prevalence among adults aged 18 and over: United States, 2017-2018. NCHS Data Brief:1-8

Patel SA, Winkel M, Ali MK, Narayan KM, and Mehta NK (2015) Cardiovascular mortality associated with 5 leading risk factors: national and state preventable fractions estimated from survey data. Ann Intern Med 163:245-253.

Peixoto P, Aires RD, Lemos VS, Bissoli NS, and Santos RLD (2017) GPER agonist dilates mesenteric arteries via PI3K-Akt-eNOS and potassium channels in both sexes. Life Sci 183:21-27.

Pollock DM and Pollock JS (2001) Evidence for endothelin involvement in the response to high salt. Am J Physiol Renal Physiol 281:F144-F150.

Pollock JS and Pollock DM (2019) SONAR propels endothelin A receptor antagonists to success. Nat Rev Nephrol 15:461-462.

Qiao C, Ye W, Li S, Wang H, and Ding X (2018) Icariin modulates mitochondrial function and apoptosis in high glucose-induced glomerular podocytes through $\mathrm{G}$ protein-coupled estrogen receptors. Mol Cell Endocrinol 473:146-155.

Revankar CM, Cimino DF, Sklar LA, Arterburn JB, and Prossnitz ER (2005) A transmembrane intracellular estrogen receptor mediates rapid cell signaling. Science 307:1625-1630.

Seo B, Oemar BS, Siebenmann R, von Segesser L, and Lüscher TF (1994) Both ETA and ETB receptors mediate contraction to endothelin-1 in human blood vessels. Circulation 89:1203-1208.

Speed JS, Fox BM, Johnston JG, and Pollock DM (2015) Endothelin and renal ion and water transport. Semin Nephrol 35:137-144.

Speed JS and Hyndman KA (2016) In vivo organ specific drug delivery with implantable peristaltic pumps. Sci Rep 6:26251.

Stec DE, Mattson DL, and Roman RJ (1997) Inhibition of renal outer medullary 20HETE production produces hypertension in Lewis rats. Hypertension 29:315-319.

Thomas P, Pang Y, Filardo EJ, and Dong J (2005) Identity of an estrogen membrane receptor coupled to a $\mathrm{G}$ protein in human breast cancer cells. Endocrinology 146: 624-632.

Tropea T, De Francesco EM, Rigiracciolo D, Maggiolini M, Wareing M, Osol G, and Mandalà M (2015) Pregnancy augments G protein estrogen receptor (GPER) induced vasodilation in rat uterine arteries via the nitric oxide - cGMP signaling pathway. PLoS One 10:e0141997.

Wang C, Dehghani B, Li Y, Kaler LJ, Proctor T, Vandenbark AA, and Offner H (2009) Membrane estrogen receptor regulates experimental autoimmune encephalomyelitis through up-regulation of programmed death 1. J Immunol 182:3294-3303.

Wessale JL, Adler AL, Novosad EI, Calzadilla SV, Dayton BD, Marsh KC, Winn M, Jae HS, von Geldern TW, and Opgenorth TJ (2002) Pharmacology of endothelin receptor antagonists ABT-627, ABT-546, A-182086 and A-192621: ex vivo and in vivo studies. Clin Sci (Lond) 103 (Suppl 48):112S-117S.

White DG, Cannon TR, Garratt H, Mundin JW, Sumner MJ, and Watts IS (1993) Endothelin ETA and ETB receptors mediate vascular smooth-muscle contraction. $J$ Cardiovasc Pharmacol 22 (Suppl 8):S144-S148.

Zeidel ML, Brady HR, Kone BC, Gullans SR, and Brenner BM (1989) Endothelin, a peptide inhibitor of $\mathrm{Na}(+)-\mathrm{K}(+)$-ATPase in intact renaltubular epithelial cells. Am J Physiol 257:C1101-C1107.

Address correspondence to: Dr. Eman Y. Gohar, Section of Cardio-Renal Physiology and Medicine, Division of Nephrology, Department of Medicine, University of Alabama at Birmingham, 720 20th St. S, Kaul 840, Birmingham, AL 35233. E-mail: emangohar@uabmc.edu 